\title{
Reuse of hospital bedpans
}

\author{
Reutilização de comadres hospitalares \\ Reutilización de chatas higiénicas
}

\author{
Tamires Alessandra Mineli' \\ ORCID: 0000-0002-4517-8166 \\ Denise de Andrade' \\ ORCID: 0000-0002-3336-2695 \\ Simone de Godoy' \\ ORCID: 0000-0003-0020-7645 \\ Isabel Amélia Costa Mendes' \\ ORCID: 0000-0002-0704-4319 \\ Silvia Helena Tognoli' \\ ORCID: 0000-0001-8501-1638 \\ Leila Maria Marchi-Alves' \\ ORCID: 0000-0001-9374-8074
}

'Universidade de São Paulo. Ribeirão Preto, São Paulo, Brazil.

How to cite this article: Mineli TA, Andrade D, Godoy S, Mendes IAC, Tognoli SH, Marchi-Alves LM. Reuse of hospital bedpans.

Rev Bras Enferm. 2021;74(2):e20201040. https://doi.org/10.1590/0034-7167-2020-1040

\section{Corresponding author:} Leila Maria Marchi-Alves E-mail:Imarchi@eerp.usp.br

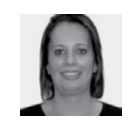

EDITOR IN CHIEF: Antonio José de Almeida Filho ASSOCIATE EDITOR: Ana Fátima Fernandes

Submission: 10-13-2020

Approval: 01-08-2021

\begin{abstract}
Objectives: to evaluate the results of two methods of hospital bedpan reprocessing. Methods: cross-sectional study. Hospital bedpans containing a biological material contamination simulator or organic matter were submitted to manual cleaning followed by disinfection with $70 \%$ alcohol solution or thermodisinfection. Permanence of simulated contamination was evaluated by using the fluorescence technique and presence of organic matter was verified by carrying out the protein detection test. Results: the contamination simulator was found in bedpans submitted to both processes. The seat was dirtier after manual cleaning $(p=0.044)$ in comparison with the result obtained with thermodisinfection. Automatized decontamination led to worse results when compared to the manual procedure for the scoop and external bottom $(p=0.000)$. The protein detection test was positive in two items after thermodisinfection. Conclusions: manual cleaning followed by rubbing with $70 \%$ alcohol solution proved more effective than automatized cleaning in the reprocessing of hospital bedpans. There are relevant issues regarding reuse of hospital bedpans.
\end{abstract}

Descriptors: Bedpans; Decontamination; Disinfection; Hygiene; Equipment Reuse

\section{RESUMO}

Objetivos: avaliar os resultados de dois métodos de reprocessamento de comadres hospitalares. Métodos: estudo transversal. Comadres hospitalares contendo simulador de contaminação por material biológico ou matéria orgânica foram submetidas a limpeza manual/desinfecção com álcool a 70\% ou termodesinfecção. A permanência de contaminação simulada foi avaliada por fluorescência e a presença de matéria orgânica pelo teste de detecção de proteína. Resultados: constatou-se a presença de simulador de contaminação nas comadres submetidas a ambos os processos. $O$ assento se mostrou mais sujo após a limpeza manual $(p=0,044)$. Nas áreas da pá e fundo externo, a descontaminação automatizada teve pior resultado quando comparada à manual $(p=0,000)$. $O$ teste de deteç̧ão de proteínas foi positivo em dois utensílios após a termodesinfecção. Conclusões: no reprocessamento de comadres hospitalares, a limpeza manual seguida de fricção com álcool a 70\% mostrou-se mais eficaz que a limpeza automatizada. Há fragilidades relativas à reutilização de comadres hospitalares. Descritores: Comadres; Descontaminação; Desinfecção; Higiene; Reutilização de Equipamento

\section{RESUMEN}

Objetivos: evaluar los resultados de dos métodos de reprocesamiento de chatas higiénicas. Métodos: estudio transversal. Chatas higiénicas conteniendo simulador de contaminación por material biológico o materia orgánica fueron sometidas a lavado manual/desinfección con alcohol al 70\% o termodesinfección. La permanencia de contaminación simulada se evaluó por fluorescencia; la presencia de material orgánico, por prueba de detección de proteínas. Resultados: se constató presencia de simulador de contaminación en chatas sometidas a ambos procesos. El asiento resultó más contaminado luego de la limpieza manual ( $p=0,044$. En la pala y el fondo externo, la descontaminación automatizada tuvo peor resultado comparada con la manual $(p=0,000)$. La prueba de detección de proteínas fue positiva en dos chatas luego de la termodesinfección. Conclusiones: para reprocesar chatas higiénicas, la limpieza manual seguida por fricción con alcohol al $70 \%$ resultó más eficaz que la limpieza automatizada. Se plantean interrogantes respecto de reutilizar chatas higiénicas. Descriptores: Chata Higiénica; Descontaminación; Desinfección; Higiene; Equipo Reutilizado. 


\section{INTRODUCTION}

Material reprocessing in hospitals is an object of discussion ${ }^{(1)}$ and has currently been gaining prominence in situations in which there is lack of evidence in disinfection guidelines and protocols when a response to disease outbreaks is required ${ }^{(2)}$.

When items or supplies used in health care are liable for reprocessing, it is necessary to pay special attention to cleaning, disinfection, and sterilization processes, which must be carried out thoroughly and grounded in standardizations that validate their reuse. The classification of items proposed by Earle Spaulding in 1957 categorized objects based on risk of infection and can contribute to selecting the adequate processing method. However, given the diversity of situations found in health care, this classification has risen a series of questions ${ }^{(3-5)}$.

According to Brazilian and international guidelines, and contrarily to what is proposed for critical and semicritical items, most noncritical items are reusable and can be decontaminated at the place of use, as long as there are proper conditions to do that. Theoretically, there is no risk of microbial transmission by these objects, especially considering that they must get in contact with intact skin only, never with mucous membranes. Nevertheless, health professionals must take into account the possibility of microbial transmission every time there is a breach in good practices of use, reprocessing, and storage of this type of material ${ }^{(3,5)}$.

Because of varied reasons, some researchers argued that adopting the object classification proposed by Spaulding may not be the ideal indication for reprocessing of some materials. One of these objects is hospital bedpans. They are considered noncritical items and are used for personal hygiene and collection of excretion from bedridden or weak people when its elimination in traditional toilet is no longer an option ${ }^{(6)}$.

It is important to stress that feces house an incalculable quantity of microorganisms, many of them already identified and some multiresistant. Therefore, there is speculation about the potential risk of cross infection associated with the use of bedpans. Alarmingly, using this object was related to $4 \%$ to $21 \%$ of healthcareassociated infection cases ${ }^{(7)}$. Consequently, researchers have the concern of verifying how big the load of microorganisms in the feces is and their potential of active replication and contamination, as well as of analyzing the capacity of formation and the stability of microbial biofilms on stainless steel surfaces ${ }^{(8-9)}$, the material most hospital bedpans available in Brazil are made of.

Additionally, the occupational risk of microbial transmission via hospital bedpans is diversified and increased when sanitary containers are emptied for manual cleaning by using a shower, because this procedure implies the possibility of pulverization or formation of aerosols, leading to severe infections, such as that caused by Clostridium difficile $e^{(7)}$, for instance, which provokes diarrhea.

In face of the above, it is cautious to ponder about the procedure of cleaning and decontamination of hospital bedpans. As this subject has not attracted the interest of researchers, there are few studies that evaluated the biological risk of different reprocessing methods for these items and discussed the implications of each procedure ${ }^{(7)}$.
Taking into account the controversies and gaps in the literature regarding the best reprocessing method for noncritical items and the relevance of hospital bedpans as a source of contamination, it is pertinent to question which method is more adequate to clean and disinfect these objects. The purpose of the present study was to evaluate two processing methods for noncritical items used in healthcare facilities in search of evidence that allows to rationalize the choice before the range of practical options in this field of activity. The focus was to seek indicators that could contribute to establishing safe conditions to reuse nonsterilized objects.

\section{OBJECTIVES}

To evaluate the results of two hospital bedpans reprocessing methods.

\section{METHODS}

\section{Ethical aspects}

Because the present study did not involve human beings, it was not submitted to ethical analysis with a research ethics committee. However, the study execution was authorized by the institution where data were collected.

\section{Study design, period, and location}

Descriptive, exploratory, and cross-sectional study carried out in a tertiary hospital complex located in the interior of the state of São Paulo, Brazil. Data were collected between May and June 2019. The instrument SQUIRE 2.0 was used to guide the study methodology.

\section{Sample}

The examined objects were hospital bedpans made of rustproof material, with dimensions $40 \mathrm{~cm} \times 30 \mathrm{~cm} \times 10 \mathrm{~cm}$, available at the institution. The study had two phases. The first focused on evaluating the permanence of simulated microorganisms in 130 hospital bedpans impregnated with a solution that mimics contamination with biological material (Glo Germ ${ }^{\mathrm{TM}}$ Liquid) and submitted to two different processing methods (groups 1 and 2). The second phase consisted of detecting protein residues in 50 hospital bedpans used by inpatients which were submitted to manual cleaning followed by disinfection with a $70 \%$ ethyl alcohol solution (group 1) or automatized cleaning (group 2).

Determination of the type of processing used in each object was carried out by randomly picking the procedure to which the first item to be decontaminated would be submitted, with the following item going through the other procedure, and this alternation was repeated with the set of bedpans to be processed. This procedure was executed weekly, on Mondays, the day established for data collection for being the one with the highest referral flow of the item to the Materials and Sterilization Center (CME, as per its acronym in Portuguese). Consequently, all hospital bedpans reprocessed at the institution on the day chosen for data collection over the study period were part of the sample. 


\section{Study protocol}

To simulate contamination, the items were inoculated with $20 \mathrm{~mL}$ of Glo Germ ${ }^{\mathrm{TM}}$ Liquid (Glo Germ Co, Moab, Utah), a product made primarily of melamine resin containing particles the same size of microorganisms' (around 0.5 to $4.0 \mu \mathrm{m}$ in diameter). Therefore, it qualitatively mimics the transmissibility of microbial species. These particles become visible when ultraviolet (UV) light is shed on them ${ }^{(10-11)}$.

After uniform spreading of Glo Germ on the internal and external surfaces of hospital bedpans, the first set of objects (group 1) was submitted to the manual cleaning process followed by disinfection with $70 \%$ ethyl alcohol. Dirt removal was favored by use of running water and the concentrated alkaline detergent Prolystica $2 \times$ Enzymatic Presoak and Cleaner (STERIS ${ }^{\circ}$ ). The detergent solution was diluted in water in the proportion $1 \mathrm{~mL} / \mathrm{L}$ and put inside a big and deep immersion tank designed to help clean the items. The bedpans were immersed in this tank and kept there for five minutes. After manual cleaning, the objects were rinsed with cold water jets. Subsequently, drying was carried out by applying absorbent sterile compresses manufactured with four layers of hydrophilic cotton fabric, with dimensions 45 $\mathrm{cm} \times 50 \mathrm{~cm}$. Last, $70 \%$ ethyl alcohol was applied to the surface of the bedpans.

The second set of objects (group 2) was submitted to thermodisinfection with no previous washing, in accordance with the procedure described by Rutala et al. ${ }^{(5)}$. A Cisa 155/2P/E/TS/ SV thermodisinfector, available at the institution, was used. This washer carries out thermal disinfection by combining a repetition linear movement system and high-pressure water jets, which are applied on the entire surface of the items. Temperature control ranges from $45^{\circ} \mathrm{C}$ (washing) to $93^{\circ} \mathrm{C}$ (disinfection). The product used in the procedure was enzymatic detergent. Equipment performance qualification was attested periodically by means of reports issued by a specialized company to the unit, which proved the evaluation of the equipment functioning, according to recommendations of regulatory agencies. Similar to what happened with the objects in group 1, the decontamination step was carried out in the dirty area of $\mathrm{CME}$, and after disinfection the items were stored in its clean area.

Fluorescence was used to visually detect spots with the presence of Glo Germ solution after manual cleaning followed by application of $70 \%$ ethyl alcohol or automatized cleaning. The instrument used as a source of UV light was a hand lamp with wavelength of $365 \mathrm{~nm}$. The objects were photographed under UV light by using a 12 -megapixel camera, $f / 1.8$ aperture, and $5 \times$ digital zoom. It was possible to spot the contaminated areas by visualizing the images. To facilitate evaluation, the surface of the bedpans was split into distinct areas: scoop (lowered area of the seat), seat, inner surface, handgrip, outer bottom, and outer side.

Detection of protein residues was carried out by using a VERIFY RESI-TEST $^{\text {TM }}$ (STERIS ${ }^{\circ}$ cleaning indicator, designed to have high sensitivity. A swab was carefully rubbed against the entire surface of the bedpans and put inside a tube containing a solution whose color changes when in contact with proteins. The tube was then shaken for five seconds for coloring reading. When the solution remained brown or light green, the object was considered clean.
The solution's turning blue indicated that the item was dirty or that the cleaning/disinfection procedure had not been approved.

\section{Results analysis}

The collected data were submitted to appropriate codification, typed into a data bank after the formulation of a dictionary (code book) in a Windows XP Microsoft Excel (Microsoft Co, USA) spreadsheet, and validated by means of double typing. Descriptive analyses (calculation of absolute frequencies, percentages, means, standard deviations, and medians) and description of proportional differences between the groups were carried out by using IBM SPSS Statistics version 25 with a $95 \%$ confidence interval. A normality test was applied to verify normality in the distribution of the studied variables. The examined variables of interest were permanence of contamination simulator and presence of proteins on the surface of bedpans submitted to both analyzed decontamination processes. These variables were submitted to the Mann-Whitney test and Fisher's exact test, and the adopted level of significance was $5 \%(p<0.05)$. Therefore, the present study evaluated the impact of two reprocessing methods (manual cleaning and automatized cleaning) on cleaning and decontamination of hospital bedpans.

\section{RESULTS}

The results of the processes of cleaning and disinfection of 180 hospital bedpans divided into two groups were evaluated, with the presence of a contamination simulator examined in 130 objects (Tables 1, 2, and 3) and the protein detection test applied to 50 items (Table 4).

On visual inspection, all hospital bedpans looked clean. However, the protein detection test was positive for two objects processed in the thermodisinfector (Table 4).

Table 1 - Distribution of absolute $(n)$ and relative (\%) frequency of presence of contamination simulator in hospital bedpans submitted to manual and automatized cleaning, Ribeirão Preto, São Paulo, Brazil, 2019

\begin{tabular}{lcccc}
\hline $\begin{array}{l}\text { Presence of } \\
\text { contamination } \\
\text { simulator }\end{array}$ & $\begin{array}{c}\text { Manual cleaning } \\
(\mathbf{n}=\mathbf{6 4})\end{array}$ & $\begin{array}{c}\text { Process } \\
\text { Automatized cleaning } \\
(\mathbf{n}=\mathbf{6 6})\end{array}$ & $\begin{array}{c}\text { Total } \\
(\mathbf{N}=\mathbf{1 3 0})\end{array}$ \\
\hline Yes & $\mathrm{n}$ & 34 & 49 & 83 \\
& $\%$ & 53.1 & 74.2 & 63.8 \\
No & $\mathrm{N}$ & 30 & 17 & 47 \\
& $\%$ & 46.9 & 25.8 & 36.2 \\
\hline
\end{tabular}

Table 2 - Presence of contamination simulator in hospital bedpans submitted to manual and automatized cleaning according to the number of contaminated areas, Ribeirão Preto, São Paulo, Brazil, 2019

\begin{tabular}{lccc}
\hline $\begin{array}{l}\text { Presence of } \\
\text { contamination } \\
\text { simulator }\end{array}$ & $\begin{array}{c}\text { Manual cleaning } \\
(\mathbf{n = 6 4 )}\end{array}$ & $\begin{array}{c}\text { Process } \\
\text { Automatized cleaning } \\
(\mathbf{n = 6 6 )}\end{array}$ & $\boldsymbol{p}^{*}$ \\
\hline Mean & 1.5 & 2.5 & \\
Median & 1.0 & 3.0 & \\
Standard deviation & 1.7 & 1.9 & 0.003 \\
Minimum & 0 & 0 & \\
Maximum & 6 & 8 & \\
\hline Note: ${ }^{\text {Mann-Whitney test. }}$ & & &
\end{tabular}


Table 3 - Presence of contamination simulator in hospital bedpans submitted to manual and automatized cleaning as a function of the area of the object, Ribeirão Preto, São Paulo, Brazil, 2019

\begin{tabular}{|c|c|c|c|c|c|c|}
\hline \multirow{3}{*}{$\begin{array}{l}\text { Presence of } \\
\text { contamination } \\
\text { simulator } \\
\text { Local }\end{array}$} & \multirow[b]{3}{*}{$\begin{array}{l}\text { Number } \\
\text { of areas }\end{array}$} & \multicolumn{4}{|c|}{ Process } & \multirow{3}{*}{$p^{*}$} \\
\hline & & \multicolumn{2}{|c|}{$\begin{array}{c}\text { Manual } \\
\text { cleaning } \\
(n=64)\end{array}$} & \multicolumn{2}{|c|}{$\begin{array}{l}\text { Automatized } \\
\text { cleaning } \\
(n=66)\end{array}$} & \\
\hline & & $\mathbf{N}$ & $\%$ & $\mathbf{n}$ & $\%$ & \\
\hline \multirow[t]{4}{*}{ Inner surface } & 0 & 43 & 67.2 & 50 & 75.8 & \multirow{4}{*}{0.098} \\
\hline & 1 & 15 & 23.4 & 06 & 9.1 & \\
\hline & 2 & 05 & 7.8 & 09 & 13.6 & \\
\hline & 3 & 01 & 1.6 & 01 & 1.5 & \\
\hline \multirow[t]{4}{*}{ Scoop } & 0 & 62 & 96.9 & 48 & 72.7 & \multirow{4}{*}{0.000} \\
\hline & 1 & - & - & - & - & \\
\hline & 2 & 01 & 1.6 & 06 & 9.1 & \\
\hline & 3 & 01 & 1.6 & 12 & 18.2 & \\
\hline \multirow[t]{4}{*}{ Seat } & 0 & 39 & 60.9 & 54 & 81.8 & \multirow{4}{*}{0.044} \\
\hline & 1 & 07 & 10.9 & 03 & 4.5 & \\
\hline & 2 & 15 & 23.4 & 06 & 9.1 & \\
\hline & 3 & 03 & 4.7 & 03 & 4.5 & \\
\hline \multirow[t]{4}{*}{ Outer side } & 0 & 58 & 90.6 & 57 & 86.4 & \multirow{4}{*}{0.918} \\
\hline & 1 & 02 & 3.1 & 02 & 3.0 & \\
\hline & 2 & 03 & 407 & 05 & 7.6 & \\
\hline & 3 & 01 & 1.6 & 02 & 3.0 & \\
\hline \multirow[t]{4}{*}{ Handgrip } & 0 & 63 & 98.4 & 64 & 97 & \multirow{4}{*}{1.000} \\
\hline & 1 & 01 & 1.6 & 01 & 1.5 & \\
\hline & 2 & - & - & 01 & 1.5 & \\
\hline & 3 & - & - & 01 & 1.5 & \\
\hline \multirow[t]{4}{*}{ Outter bottom } & 0 & 60 & 93.8 & 48 & 72.7 & \multirow{4}{*}{0.000} \\
\hline & 1 & 02 & 3.1 & 02 & 3.0 & \\
\hline & 2 & 02 & 3.1 & 05 & 7.6 & \\
\hline & 3 & - & - & 11 & 16.7 & \\
\hline
\end{tabular}
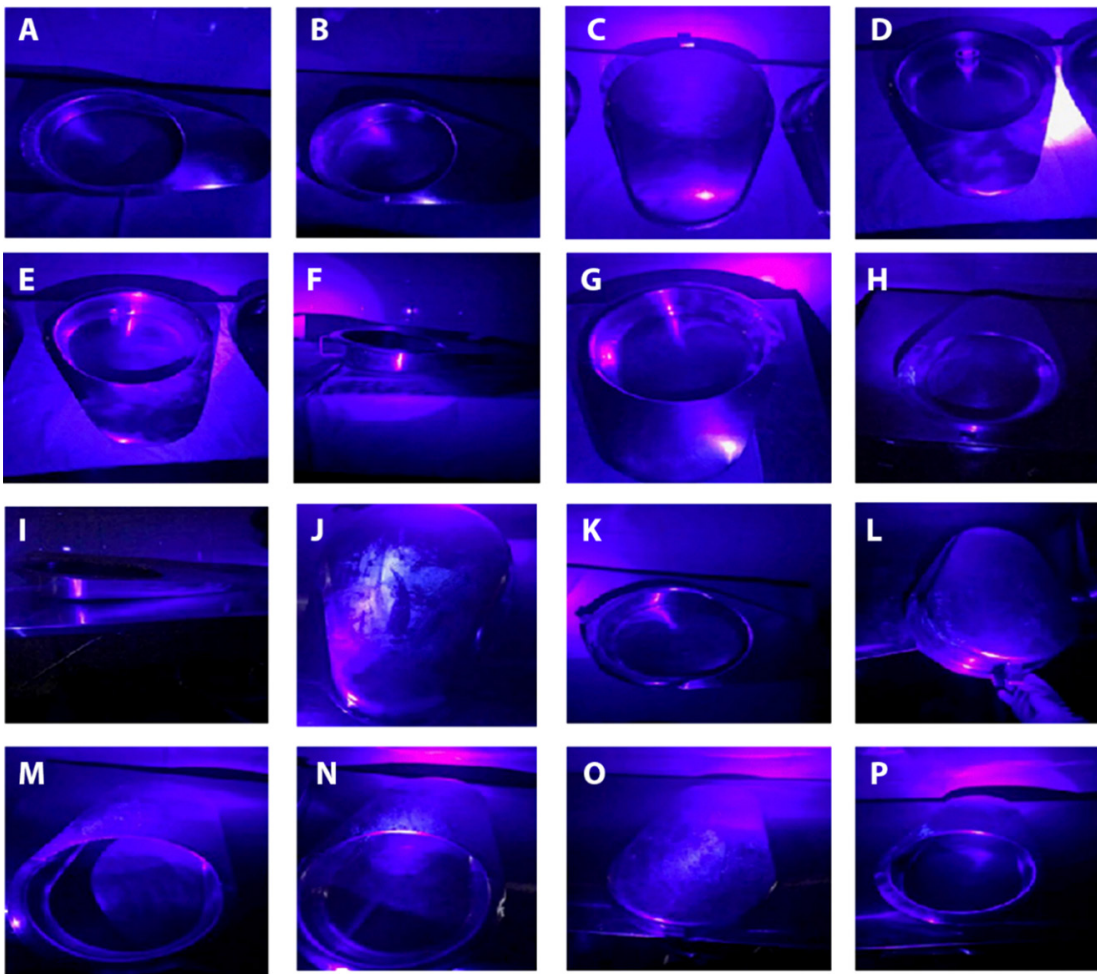

Figure 1 - Pictures of hospital bedpans after manual $(\mathrm{A}$ to $\mathrm{H})$ and automatized (I to $\mathrm{P})$ cleaning. Areas with a pink glow contained the contamination simulator, Ribeirão Preto, São Paulo, Brazil, 2019
Table 4 - Absolute ( $n$ ) and relative (\%) distribution of presence of proteins in hospital bedpans submitted to manual and automatized cleaning, Ribeirão Preto, São Paulo, Brazil, 2019

\begin{tabular}{lccccc}
\hline $\begin{array}{l}\text { Presence of } \\
\text { protein }\end{array}$ & $\begin{array}{c}\text { Manual } \\
\text { cleaning } \\
(\mathbf{n = 2 5 )}\end{array}$ & $\begin{array}{c}\text { Putomatized } \\
\text { cleaning } \\
(\mathbf{n}=\mathbf{2 5})\end{array}$ & $\begin{array}{c}\text { Total } \\
(\mathbf{N}=5 \mathbf{5 0})\end{array}$ & $\boldsymbol{p}^{*}$ \\
\hline \multirow{2}{*}{ Yes } & $\mathrm{n}$ & 0 & 02 & 02 & \\
& $\%$ & - & 8 & 4 & 0.489 \\
\multirow{2}{*}{ No } & $\mathrm{n}$ & 25 & 23 & 48 & \\
& $\%$ & 100 & 92 & 96 & \\
\hline
\end{tabular}

The bedpans were photographed after the manual and automatized cleaning procedures so the areas that still showed the contamination simulator could be visualized (Figure 1).

\section{DISCUSSION}

The data collected in the present study indicated weaknesses in both analyzed reprocessing methods, with automatized cleaning showing worse results than manual cleaning followed by decontamination with $70 \%$ ethyl alcohol. It is believed that the shape of the bedpans may have hindered automatized cleaning, since the thermodisinfector applied high-pressure water jets and the swirling may have not been enough to reach all areas with dirt. It can also be speculated that previous manual friction helps the cleaning process and other steps of item reprocessing.

By opting for manual cleaning associated with use of $70 \%$ ethyl alcohol as a standard procedure to decontaminate bedpans, the institution where data were collected adopted intermediate-level processing. Using the thermodisinfector, in turn, is characterized as high-level disinfection ${ }^{(12-13)}$. Neither process is usually indicated for cleaning and disinfection of noncritical items.

All hospital bedpans available at the institution were made of rustproof material and reused after going through decontamination. Similarly, a study involving 93 countries showed that most institutions had multipleuser $(76 \%)$ and stainless steel (51\%) hospital bedpans, meaning they were submitted to reprocessing ${ }^{(14)}$, which increased the risk of cross infection.

A study that evaluated cleaning in 135 hospital bedpans made of different materials identified that polypropylene appliances were more effectively cleaned in comparison with those made of stainless steel. In addition to automatized cleaning, the researchers examined three cleaning and disinfection methods: combination of $1.5 \%$ chlorhexidine and $15 \%$ cetrimide, $7.5 \%$ benzalkonium chloride, and detergent only. The colony-forming unit assay showed that adding disinfecting solution did not increase decontamination efficacy in 
comparison with the results obtained when detergent was used in isolation. Authors stressed the need to identify the exact share of contribution of bedpans to infection transmission and make efforts to carry out effective and safe decontamination of these items ${ }^{(15)}$.

In addition to material type, other factors can affect the efficacy of the cleaning process, such as dirt quantity and type, water quality and temperature, availability and use of cleaning products, and training of the professional team ${ }^{(1)}$.

A study that involved 14 hospitals located in different Brazilian Regions showed that $80 \%$ of these institutions performed manual cleaning of bedpans and $14 \%$ resorted to the automatized process, with $57 \%$ applying chemical disinfection and $29 \%$ the thermal procedure. Regarding cleaning and processing location, $57 \%$ of the institutions carried out processing at care units, $29 \%$ performed cleaning at care units and processing at $\mathrm{CME}$, and $14 \%$ executed the two steps at $\mathrm{CME}^{(16)}$.

The importance of recommending the application of $70 \%$ ethyl alcohol on clean surfaces because of its microbicide action ${ }^{(17)}$ was demonstrated in the present study, since bedpans submitted to friction with alcoholic solution showed better results compared to those cleaned with the automatized procedure.

Comparison of the two cleaning and disinfection methods showed that the number of areas in hospital bedpans in which the contamination simulator was visualized varied. In general, the product remained on the surface of the object more often after the procedure with the thermodisinfector. However, manual cleaning showed worse results for the seat area.

Finding that the bedpans seat was the area with more marked presence of the contamination simulator in group 1 raises concern, especially when bedpan users are patients with injuries in the sacral and gluteal regions. Contact of these body parts with the bedpan seat at the moment of vesical or intestinal elimination is inevitable ${ }^{(18)}$. Taking this fact into account, it is not correct to state that hospital bedpans get in contact with intact skin only. It must be emphasized that, in Brazil, the prevalence of pressure injuries in intensive care units ranges from $35.2 \%$ to $63.6 \%{ }^{(19)}$.

On visual inspection, all hospital bedpans submitted to manual and automatized decontamination looked clean. However, the protein detection test was positive for two bedpans processed in the thermodisinfector, a result different from that reported in the 1960s, when concern with this subject already existed. In this study, a regular dishwasher with automatic cycles was used to clean and disinfect hospital bedpans. Visual and bacteriological tests showed that this type of machine led to better and more reliable results than those obtained with previously described methods (immersion in disinfecting solution followed by rinsing with running water; pulverization with cold or hot water with jets discharged by a human operator, with no established cycle; pulverization followed by immersion in boiler; and pulverization followed by vapor injection) ${ }^{(20)}$.

It is important to stress the possibility of transmission of infection caused by Clostridium difficile via contaminated bedpans. This bacterium is considered the main cause of diarrhea in the hospital setting, and the infection can evolve into sepsis and death. Its spores can survive for long periods in contaminated surfaces ${ }^{(21-22)}$. A recent study carried out during the SARS-CoV-2 pandemic showed the presence of this virus in feces of infected patients, which suggested the risk of fecal-oral contamination. In face of the described scenario, the existence of risks and the need to invest in safe processing of hospital bedpans cannot be denied ${ }^{(23)}$.

Given the issues mentioned above, it is sensible that processing of hospital bedpans be performed with validated methods that guarantee intermediate level cleaning and disinfection ${ }^{(3,5)}$. It was also suggested that, because of the risk of microbial transmission, hospital bedpans should be sterilized after patient discharge ${ }^{(24)}$. Other researchers warned about the increase in the population of multiresistant microorganisms ${ }^{(25)}$.

Whatever the hospital bedpan processing method, it is construed that safety guarantee includes effective management of good practices in the cleaning, decontamination, and even storage procedure ${ }^{(7)}$.

Therefore, all reprocessing protocols must be validated to ensure integrity, functionality, and traceability of the items. Validating a reprocessing protocol is a complex and expensive process, but fundamental for securing quality and safety in product reuse. Additionally, treating items liable to processing by applying nonvalidated or partially validated protocols is a sanitary infraction, and the institution can be hold accountable for it in the civil, legal, and administrative spheres ${ }^{(26)}$.

\section{Study limitations}

During the manual cleaning process, specific cleaning products were used, including neutral detergent, alkaline detergent, brushes appropriate for cleaning, and 70\% ethyl alcohol. However, the efficacy of each product was not analyzed in isolation, which can be considered a limitation. Additionally, quantification and classification of the microbiota found in reprocessed bedpans could have enriched the results.

\section{Contributions to the area}

The authors believe that the findings of the present study are important evidence for the practice of item reuse. The results can contribute to designing guidelines oriented toward guaranteeing adherence to good hospital bedpan processing practices and increasing conformity rates before the wide variety of clinical situations experienced in care settings.

\section{CONCLUSIONS}

The results of the present study indicated that manual cleaning followed by friction with $70 \%$ ethyl alcohol was more effective than automatized cleaning in hospital bedpan reprocessing. The data corroborated the fragilities commonly related to reuse of items in the hospital setting.

\section{FUNDING}

Coordenação de Aperfeiçoamento de Pessoal de Nível Superior (CAPES).

\section{ACKNOWLEDGMENT}

Hospital das Clínicas da Faculdade de Medicina de Ribeirão Preto da Universidade de São Paulo. 


\section{REFERENCES}

1. World Health Organization. Pan American Health Organization. Decontamination and Reprocessing of Medical Devices for Health-care Facilities [Internet]. 2016 [cited 2020 Mar 20]. Available from: https://www.who.int/infection-prevention/publications/decontamination/en/

2. Gallandat K, Kolus RC, Julian TR, Lantagne DS. A systematic review of chlorine-based surface disinfection efficacy to inform recommendations for low-resource outbreak settings. Am J Infect Control. 2020;S0196-6553(20)30311-4. https://doi.org/10.1016/j.ajic.2020.05.014

3. Organización Panamericana de La Salud. Manual de Esterilización para Centros de Salud [Internet]. Washington, D.C.: OPS; 2008 [cited 2020 Jul 30]. Available from: https://www1.paho.org/PAHO-USAID/dmdocuments/AMR-Manual_Esterilizacion_Centros_Salud_2008.pdf

4. Spaulding EH, Emmons EK. Chemical disinfection. Am J Nurs Sci. 1958;58(9):1238-42.

5. Rutala WA, Weber DJ. Disinfection, sterilization, and antisepsis: an overview. Am J Infect Control. 2019;47S:A3-A9. https://doi.org/10.1016/j. ajic.2019.01.018

6. Toney-Butler TJ, Gaston G. Nursing Bedpan Management. In: StatPearls [Internet]. Treasure Island (FL): StatPearls Publishing; 2020 [cited 2020 May 25]. Available from: https://www.ncbi.nlm.nih.gov/books/NBK499978/

7. van Knippenberg-Gordebeke G. Bedpans and healthcare-associated infections. Hospital Health Care Europe. Int Consult [Internet]. 2012 [cited 2020 Mar 16]. Available from: https://hospitalhealthcare.com/news/bedpans-and-healthcare-associated-infections/

8. Foladori P, Cutrupi F, Segata N, Manara S, Pinto F, Malpei F, et al. SARS-CoV-2 from faeces to wastewater treatment: what do we know? a review. Sci Total Environ. 2020;743:140444. https://doi.org/10.1016/j.scitotenv.2020.140444

9. Di Lodovico S, Cataldi V, Di Campli E, Ancarani E, Cellini L, Di Giulio M. Enterococcus hirae biofilm formation on hospital material surfaces and effect of new biocides. Environ Health Prev Med. 2017;22(1):63. https://doi.org/10.1186/s12199-017-0670-3

10. Maitland J, Boyer R, Gallagher D, Duncan S, Bauer N, Kause J, et al. Tracking cross-contamination transfer dynamics at a mock retail deli market using GloGerm. J Food Prot. 2013;76(2):272-82. https://doi.org/10.4315/0362-028X.JFP-12-271

11. Schimer A, Swan C, Hughes SJ, Vasilopoulos T, Oli M, Chaudhry S, et al. Break Scrub to Take That Phone Call? J Am Coll Surg. 2018;226(6):1117-21. https://doi.org/10.1016/j.jamcollsurg.2018.03.002

12. Rutala WA, Weber DJ, Gergen MF, Gratta AR. Efficacy of a washer-pasteurizer for disinfection of respiratory - care equipament. Infect Control Hosp Epidemiol. 2000;21(5):333-6. https://doi.org/10.1086/501767

13. Agência Nacional de Vigilância Sanitária. Álcool etílico como saneante [Internet]. 2014 [cited 2020 Jun 11]. Available from: http://portal. anvisa.gov.br/anvisa-esclarece?

14. Popp W, Zorigt K, Borg M, Zerafa S, Khamis N, Damani N, et al. Global practices related to handling of faeces and urine in hospitals - results of an International Federation of Infection Control (IFIC) survey. Int J Infect Control. 2014;11:i1. https://doi.org/10.3396/IJIC.v11i1.004.15

15. Block C, Baron O, Bogokowski B, Amit P, Rubenstein E. An in-use evaluation of decontamination of polypropylene versus steel bedpans. J Hosp Infect. 1990;16(4):331-8. https://doi.org/10.1016/0195-6701(90)90005-9

16. Castro MDS, Paganini MC. Processamento de comadres e papagaios é um risco para CME? Rev. Nasce CME [Internet]. 2015 [cited 2020 May 18]. Available from: http://nascecme.com.br/processamento-de-comadres-e-papagaios-e-um-risco-para-a-cme/

17. Graziano KU, Graziano MU, Pinto FMG, Bruna CQM, Souza RQ, Lascala CA. Effectiveness of disinfection with alcohol $70 \%$ (w/v) of contaminated surfaces not previously cleaned. Rev Latino-Am Enfermagem. 2013;21(2):618-23. https://doi.org/10.1590/s0104-11692013000200020

18. Mendonça PK, Loureiro MDR, Frota OP, Souza AS. Prevention of pressures injuries: actions prescribed by intensive care unit nurses. Texto Contexto Enferm [Internet]. 2018;27(4):e4610017. https://doi.org/10.1590/0104-07072018004610017

19. Vasconcelos JMB, Caliri MHL. Nursing actions before and after a protocol for preventing pressure injury in intensive care. Esc Anna Nery. 2017;21(1):e20170001. https://doi.org/10.5935/1414-8145.20170001

20. Darmady EM, Hughes KEA, Jones JD, Prince D, Verdon P. Disinfection of bedpans. J Clin Pathol. 1961;14(1):66-8. https://doi.org/10.1136/ jcp.14.1.66

21. Daniels LM, Kufel WD. Clinical review of Clostridium difficile infection: an update on treatment and prevention. Expert Opin Pharmacother. 2018;19(16);1759-69. https://doi.org/10.1080/14656566.2018.15248720

22. Otter JA, Yezli S, French GL. The role played by contaminated surfaces in the transmission of nosocomial pathogens. Infect Control Hosp Epidemiol. 2011;32(7):687-99. https://doi.org/10.1086/660363T

23. Wu Y, Guo C, Tang L, Hong Z, Zhou J, Dong X, et al. Prolonged presence of SARS-CoV-2 viral RNA in fecal samples. Lancet Gastroenterol Hepatol. 2020;5(5):434-5. https://doi.org/10.1016/S2468-1253(20)30083-2

24. Lobè C, Boothroyd LJ, Lance JM. Bedpan processing methods: making an informed choice. Can J Infect Control. 2011 [cited 2020 Ju 5];26(3):165-71. Available from: https://ipac-canada.org/photos/custom/OldSite/cjic/vol26no3.pdf

25. McDonnell G, Burke P. Disinfection: is it time to reconsider Spaulding? J Hosp Infect. 2011;78(3):163-70. https://doi.org/10.1016/j.jhin.2011.05.002

26. Agência Nacional de Vigilância Sanitária. Nota técnica № 12/2020/SEI/GGTES/DIRE1/ANVISA [Internet]. 2020 [cited 2020 jul 25]. Available from: http://portal.anvisa.gov.br/documents/219201/4340788/Nota+Te\%C2\%B4cnica+12+GGTES.pdf/42dfec78-8651-4714-b5dd-e9840f9b6037 